\title{
Situational Analysis of Leptospirosis in Sik, Kedah, Malaysia: 2014 - 2017
}

\author{
Rakesh S.S. ${ }^{\text {afb }}$, Ismail H. ${ }^{\text {a }}$, Ja'afar M. H., Noorul Emilin ${ }^{\text {b }}$, Siti Rahmah ${ }^{\text {, }}$, Jamalul Hayatb \\ ${ }^{a}$ Department of Community Health, National University of Malaysia \\ ${ }^{\mathrm{b}}$ Sik District Health Office, Kedah, Ministry of Health Malaysia
}

\section{ABSTRACT}

INTRODUCTION: Leptospirosis is endemic in Malaysia. Over the past decade, there have been an increased in the number of leptospirosis cases and outbreaks. Previous leptospirosis studies examined the incidence rate, disease burden and risk factors for leptospirosis in Malaysia, but not at district or state level. Very little is known about the leptospirosis situation at district or state level. Therefore, we conducted a study to find out about leptospirosis situation in Sik district. MATERIALS AND METHODS: We conducted a cross-sectional study from January 2014 till December 2017 in Sik District, Kedah. Information on cases admitted to Sik hospital was obtained from the health office of Sik district. Socio-demographic data and laboratory results were obtained from the patient's hospital records. We performed a descriptive analysis, followed by univariate and multivariate analysis. RESULT: From January 2014 until December 2017, 286 suspected cases of leptospirosis were admitted to Sik Hospital. Of the 286 cases, 150 were confirmed cases of leptospirosis and 136 probable cases. In our study, teenager (11-20 years of age) and older adults (aged 51-60 years) were more prone to infection with leptospirosis. Fever, vomiting, anorexia, cough, and myalgia were common symptoms. Laboratory findings in 108 confirmed leptospirosis cases showed a high white blood cell count of more than $10 \times 10^{\circ} / \mathrm{L}$ in half of the patients $(50.0 \%$ ), a serum aspartate aminotransferase (AST) of more than $50 \mathrm{U} / \mathrm{L}$ in 41 cases (38.0\%), a platelets count of less than $150 \mathrm{X} 10^{9} / \mathrm{L}$ in 39 cases (36.1\%), a serum creatinine kinase more than $308 \mathrm{U} / \mathrm{L}$ in 39 cases $(36.1 \%)$ and serum alanine aminotransferase (ALT) less than $50 \mathrm{U} / \mathrm{L}$ in 33 cases (30.6\%). Multivariate analysis showed leptospirosis infection was associated with cough $(p=0.02 .95 \% \mathrm{CI}=0.28-0.91)$ and abdominal pain $(p=0.03,95 \% \mathrm{CI}=1.07-4.93)$. In our study, a higher number of leptospirosis cases were due to household infection compared to recreational activities. CONCLUSION: Teenagers and the elderly were more prone to leptospirosis infection, and the trend of household infection is increasing compared to recreational activities. Therefore, by knowing the current situation, the causes and the source of infection will help in the development of better control and prevention measures for leptospirosis.

KEYWORDS: Leptospirosis, current situation, Sik

\section{INTRODUCTION}

Leptospirosis is recognised globally as a critical re-emerging bacterial zoonotic disease, especially in heavily precipitated tropical and subtropical areas'.

Corresponding Author:

Dr. Halim bin Ismail

Department of Community Health,

National University of Malaysia

Jalan Yaacob Latif

Bandar Tun Razak, 56000

Wilayah Persekutuan Kuala Lumpur, Malaysia.

Tel No: +60126013403

Email: drhalimismail@yahoo.com
Leptospirosis poses a serious public health problem for developing countries such as Malaysia, Thailand and India. Leptospirosis usually spreads among animals, and sometimes infection occurs from animals to human. A study by Javier Millan et al. ${ }^{2}$ in Spain, found many wild and domestic carnivores carry leptospires in renal tubules, and these animals may be asymptomatic when shredding leptospira in their urine. ${ }^{3}$ Leptospirosis infections occur when one is directly and indirectly exposed to the environment contaminated with leptospire-containing animal urine., 4 Leptospires can 
survive for months if the surrounding conditions are suitable. Leptospires strive in temperature of $28^{\circ} \mathrm{C}$ $32^{\circ} \mathrm{C}$ and at a neutral or slightly alkaline $\mathrm{pH} .{ }^{3}$ The typical route of entry for pathogenic leptospires is through skin abrasion, cuts, eyes, nose, mouth and genital tract of infected animals. ${ }^{6,7}$ Almost 300 pathogenic serovars have been classified. Rodents together with dogs, cattle, swine and insectivores are mammalian host suitable for these pathogenic leptospires. ${ }^{8}$ Incubation period for leptospirosis is usually between 2-30 days. It has a biphasic disease pattern with an acute phase lasting from 7-10 days and an immune phase producing immunoglobulin to eliminate the organism from the host. ${ }^{9}$ Leptospires are present in the blood after 4 to 10 hours of infections and can be detected within a few hours to 7 days of illness. ${ }^{10}$ Studies in Thailand showed that rats were an essential reservoir for leptospirosis, followed by dogs with a seroprevalence of $11 \%$.

Risk factor for leptospirosis includes specific type of occupation such as farming, slaughtering, people working with water supply and those working in drains and drainage galleries. Leptospirosis is also common in people working in sewers, waste collection and road sweepers. ${ }^{4}$ One of the major problems faced by developing countries is sanitation and waste disposal leading to the occurrences of several infectious diseases, including leptospirosis infection. In recent years, numerous cases of leptospirosis occurring in the household have been reported primarily in rats infested houses, poor sanitation and those with low socialeconomic status. Garbage, waste disposal and sewage lead to an increase in the number of rodents resulting in an increased risk of leptospirosis infection, especially in urban slumps. ${ }^{4}$ Occupation is known to be the leading risk factor for leptospirosis for decades. Nevertheless, recent studies have shown there is a shift in the risk of leptospires infection from occupation to recreational activity. ${ }^{11}$ Recreational activities pose an increased risk for leptospirosis infection, particularly among those going for freshwater swimming, those who like rafting, kayaking and canoeing. Other events, such as fishing, hunting, cave exploration, hiking and trail biking increases the risk of travellers becoming infected with leptospirosis. ${ }^{12}$

Sik is a district in Kedah with over 69,800 population, most of the people here work as farmers and rubber tappers. It has a warm, humid, and tropical climate with high rainfall which is ideal for leptospirosis survival and transmission. So far, no studies have been done in Sik to find out the magnitude and real problem of the disease. Therefore, the objective of this study was to identify current epidemiology and trends in human leptospirosis, using data from descriptive epidemiology, laboratory test and disease notification. Furthermore, we would also like to find out the effectiveness of current promotion strategies against leptospirosis.

\section{MATERIALS AND METHODS}

We conducted a cross-sectional study involving all notified leptospirosis cases admitted to Sik Hospital from January 2014 - December 2017. There were 286 suspected leptospirosis cases reported to the Sik District Health office during that period. However, only 200 cases were enrolled for this study as medical records for the remaining cases were not found or had missing data. One hundred eight cases were confirmed cases, and 92 cases were probable cases. Probable leptospirosis cases had a positive rapid test and a negative or equivocal MAT test result, whereas confirmed leptospirosis cases had a positive rapid test and a positive MAT test. All cases were notified to the Sik District Health Office using case investigation form for leptospirosis infection by the Ministry of Health Malaysia (KKM / BKP / ZOONOSIS / LEPTO / 1 / 2011). Socio-demographic data and laboratory results were obtained from the patient's hospital records.

\section{Ethical approval}

This study was approved by the Malaysian Research Ethics Committee (NMRR-18-1027-41347).

\section{RESULTS}

Majority of the 108 confirm leptospirosis patients were men $(65.7 \%)$, with a mean age of $36.3 \pm 21.65$ years (Table 1). Most patients were of Malay ethnicity and self -employed. Fever (98.1\%), vomiting (57.4\%), reduced appetite (54.6\%), cough (50.0\%), and myalgia (44.4\%) (Table II) were the typical clinical symptoms at admission in confirmed cases of leptospirosis. None of the cases had jaundice. 
Table 1. Socio-demographic Profile of Leptospirosis Cases in Sik district $(\mathrm{n}=200)$

\begin{tabular}{|c|c|c|c|}
\hline \multirow[t]{2}{*}{ Variable } & & \multicolumn{2}{|c|}{ Leptospirosis (n, \%) } \\
\hline & & Confirm & probable \\
\hline \multirow[t]{7}{*}{ Age groups } & $1-10$ & $21(6.2)$ & $7(6.0)$ \\
\hline & $11-20$ & $74(21.8)$ & $37(31.9)$ \\
\hline & $21-30$ & $57(16.8)$ & $20(17.2)$ \\
\hline & $31-40$ & $37(10.9)$ & $17(14.7)$ \\
\hline & $41-50$ & $36(10.6)$ & $15(14.7)$ \\
\hline & $51-60$ & $60(17.6)$ & $10(8.6)$ \\
\hline & $>60$ & $55(16.2)$ & $10(8.6)$ \\
\hline \multirow[t]{2}{*}{ Gender } & Female & $37(34.3)$ & $34(37.0)$ \\
\hline & Male & $71(65.7)$ & $58(63.0)$ \\
\hline \multirow[t]{2}{*}{ Race } & Malay & 103(95.4) & $88(95.7)$ \\
\hline & Non- Malay & $5(4.6)$ & $4(4.3)$ \\
\hline \multirow[t]{2}{*}{ Residence } & Village & $100(92.6)$ & $81(88.0)$ \\
\hline & Non-village & $8(7.4)$ & $11(12.0)$ \\
\hline \multirow[t]{5}{*}{ Occupation } & Government & $7(6.5)$ & $8(8.7)$ \\
\hline & Private & $6(9.4)$ & $12(13.0)$ \\
\hline & Student & $34(31.5)$ & $25(27.2)$ \\
\hline & Self -employed & $37(34.3)$ & $26(28.3)$ \\
\hline & Not working & $24(22.2)$ & $21(22.8)$ \\
\hline
\end{tabular}

$\mathrm{SD}=$ Standard deviation

* Self-employed: farmers, rubber tapper, labour worker; own small business and doing odd jobs.

The laboratory results showed confirmed leptospirosis cases had high white blood cell of more than $10 \times 10^{9}$ / $\mathrm{L}$ in $50 \%$ of cases, serum aspartate aminotransferase (AST) more than $50 \mathrm{U} / \mathrm{L}(38.0 \%)$, platelets count less than $150 \times 10^{9} / \mathrm{L}(36.1 \%)$, serum creatinine kinase more than $308 \mathrm{U} / \mathrm{L}(36.1 \%)$ and serum alanine aminotransferase (ALT) more than $50 \mathrm{U} / \mathrm{L}(30.6 \%)$ (Table III).

On performing a chi-square test, cough and abdominal pain were significantly associated with confirmed leptospirosis cases. In contrast, none of the laboratory tests showed any significant association with confirmed leptospirosis cases. On performing simple logistic regression, cough $(p=0.02)$ and abdominal pain $(p=0.03)$ had a significant association with confirmed leptospirosis cases and in multiple logistic regression cough $(p=0.02,95 \% \mathrm{CI}=0.28-0.91)$ and abdominal pain $(p=0.03,95 \% \mathrm{CI}=1.07-4.93)$ were still associated with confirmed leptospirosis cases (Table $4 \& 5$ ).
Table II. Clinical Characteristics and source of infection of Leptospirosis patients $(n=200)$

\begin{tabular}{|c|c|c|c|}
\hline \multirow[t]{2}{*}{ Variable } & & \multicolumn{2}{|c|}{ Leptospirosis (n, \%) } \\
\hline & & Confirm & probable \\
\hline Duration of fever & None & $1(0.9)$ & $7(7.6)$ \\
\hline \multirow[t]{2}{*}{ (days) } & $1-5$ & $81(75.0)$ & $67(72.8)$ \\
\hline & $>5$ & $26(24.1)$ & $18(19.6)$ \\
\hline Fever & & $106(98.1)$ & $86(93.5)$ \\
\hline Chills & & $17(15.7)$ & $15(16.3)$ \\
\hline Rigor & & $15(13.9)$ & $10(10.9)$ \\
\hline Vomiting & & $62(57.4)$ & $54(58.7)$ \\
\hline Diarrhoea & & $35(32.4)$ & $31(33.7)$ \\
\hline Cough & & $54(50)$ & $31(33.7)$ \\
\hline Myalgia & & $48(44.4)$ & $47(51.1)$ \\
\hline Arthralgia & & $31(28.7)$ & $20(21.7)$ \\
\hline Headache & & $26(24.1)$ & $15(16.3)$ \\
\hline Abdominal pain & & $13(12.0)$ & $22(23.9)$ \\
\hline Reduced appetite & & $59(54.6)$ & $42(45.7)$ \\
\hline Jaundice & & $0(0.00)$ & $0(0.00)$ \\
\hline Hepatomegaly & & $1(.9)$ & $0(0.00)$ \\
\hline Dyspnea & & $6(5.6)$ & $6(6.5)$ \\
\hline $\begin{array}{l}\text { Abnormal } \\
\text { auscultation }\end{array}$ & & $9(8.3)$ & $0(0.00)$ \\
\hline + Hypotension & & $4(3.7)$ & $2(2.2)$ \\
\hline *Haemorrhage & & $3(2.8)$ & $1(1.1)$ \\
\hline \multirow{5}{*}{$\begin{array}{l}\text { Source of } \\
\text { infection }\end{array}$} & Recreation activity & $19(17.6)$ & 17(18.5) \\
\hline & $\begin{array}{l}\text { Household (rats in } \\
\text { the house) }\end{array}$ & $36(33.3)$ & $52(56.5)$ \\
\hline & Occupation & $13(12.0)$ & $15(16.3)$ \\
\hline & Not known & $30(27.8)$ & $7(7.6)$ \\
\hline & \# Other causes & $10(9.3)$ & $1(1.1)$ \\
\hline
\end{tabular}

+ Systolic blood pressure $<90 \mathrm{~mm} \mathrm{Hg}$, diastolic blood pressure $<60 \mathrm{~mm}$ $\mathrm{Hg} *$ Hemoptysis, hematuria, bleeding of the gums, or hematemesis. \# Flooding, an outbreak of leptospirosis, GFS water supply

\section{DISCUSSION}

This is the first cross-sectional study carried out from January 2014 till December 2017 to determine the leptospirosis situation in Sik. During this period, a total of 108 patients had confirmed leptospirosis infection with positive rapid and MAT test result. Majority of patients were men $(n=71,65.7 \%)$ and of Malay ethnicity $(\mathrm{n}=103,95.4 \%)$ with a mean age of $36.87( \pm 21.83)$ years. A study done in India on 232 leptospirosis patients showed a mean age of $32.6(\underline{\underline{ \pm}} 0.7)$ years, ${ }^{13}$ which is almost similar to our research. Similarly, a study 
conducted in Iran showed a mean age of $49.3( \pm 13.3)$ years, ${ }^{14}$ meanwhile a study in the northern state of Malaysia among town service workers found their mean age was $42.1( \pm 8.38)$ years ${ }^{15}$ which was much higher than this study.

Table III. Initial Laboratory Findings amongst Leptospirosis Patients $(\mathrm{n}=200)$

\begin{tabular}{|c|c|c|c|}
\hline \multirow{2}{*}{\multicolumn{2}{|c|}{ Variables }} & \multicolumn{2}{|c|}{ Leptospirosis (n, \%) } \\
\hline & & Confirm & probable \\
\hline \multicolumn{4}{|c|}{ Creatinine Kinase } \\
\hline & $>308 \mathrm{U} / \mathrm{L}$ & $39(36.1)$ & $37(40.2)$ \\
\hline \multicolumn{4}{|c|}{ Alkaline Phosphatase } \\
\hline & $>300 \mathrm{U} / \mathrm{L}$ & $4(3.7)$ & $3(3.3)$ \\
\hline \multicolumn{4}{|c|}{ Alanine Aminotransferase (ALT) } \\
\hline & $>50 \mathrm{U} / \mathrm{L}$ & $33(30.6)$ & $27(29.3)$ \\
\hline \multicolumn{4}{|c|}{ Aspartate Aminotransferase (AST) } \\
\hline & $>50 \mathrm{U} / \mathrm{L}$ & $41(38.0)$ & $38(41.3)$ \\
\hline \multicolumn{4}{|c|}{ Serum Creatinine } \\
\hline & $>85 \mathrm{umol} / \mathrm{L}$ & $24(22.2)$ & $22(23.9)$ \\
\hline \multicolumn{4}{|l|}{ HCT } \\
\hline & $<36 \%$ & $22(20.4)$ & $21(22.8)$ \\
\hline \multicolumn{4}{|l|}{ Urea } \\
\hline & $>7.2 \mathrm{mmol} / \mathrm{L}$ & $24(22.2)$ & $19(20.7)$ \\
\hline \multicolumn{4}{|c|}{ Total Bilirubin } \\
\hline & $>21 \mathrm{umol} / \mathrm{L}$ & $28(25.9)$ & $27(29.3)$ \\
\hline \multicolumn{4}{|l|}{ Platelets } \\
\hline & $<150 \times 10^{9} / \mathrm{L}$ & $39(36.1)$ & $33(35.9)$ \\
\hline \multicolumn{4}{|c|}{ Haemoglobin } \\
\hline & $<11 \mathrm{~g} / \mathrm{dL}$ & $14(13.0)$ & $10(10.9)$ \\
\hline \multicolumn{4}{|c|}{ White Blood Cell } \\
\hline & $>10 \times 10^{9} / \mathrm{L}$ & $54(50.0)$ & $42(45.7)$ \\
\hline
\end{tabular}

In our study, age category between $11-20$ years was the highest group with leptospirosis infection in confirmed leptospirosis cases followed by an elderly group between 51-60 years of age. A study conducted in India among 232 leptospirosis patients found most of them were within the range of $20-40$ years $^{13}$ and a study conducted in New Zealand showed patients were mainly age between 25-44 years with a peak incidence between 35-44 age group. ${ }^{16}$ In Mazandaran Province Iran, maximum cases were aged between 40 to 55 years, ${ }^{14}$ which is much higher than our study finding. Most of the patients in our study were self-employed, working mainly as farmers, rubber tappers, labour workers, own small business and doing odd jobs. This was followed by students. Studies have shown working as a farmer and doing outdoor jobs increases the risk of getting leptospirosis. A study done in Waikato new Zealand showed farmers were the most common occupation susceptible to leptospirosis infection. ${ }^{17}$ Similar finding was also noted in a study done in Iran, where most of them were farmers. ${ }^{14}$ In our study, cough $(p=0.02,95 \%$ $\mathrm{CI}=0.28-091)$ and abdominal pain $(p=0.03,95 \% \mathrm{CI}=$ 1.07-4.93) was highly associated with leptospirosis.

No other clinical or laboratory test showed any significant association with leptospirosis. Most of the patients in our study had fever, followed by vomiting, anorexia, cough, and myalgia. These findings were similar to a study done among 201 patients in Brazil, where the typical symptoms were fever, jaundice, myalgia, headache, vomiting and chills. ${ }^{18}$ However, study findings from a study in Argentina were slightly different as the common symptoms were fever, myalgia and headache. ${ }^{19}$ Another study in Tanzania on 870 patients showed common symptoms for leptospirosis infection to be fever, rigor, headache and cough which differs from our findings. ${ }^{20}$

For laboratory findings, $50.0 \%$ of the patients had raised white blood count $(n=54), 38.0 \%$ of patients had raised serum aspartate aminotransferase (AST) $(n=41), 36.1 \%$ of the patients had reduced platelets count $(n=39)$, meanwhile, $36.1 \%$ of patients had increased serum

Table IV. Association between sign and symptom with confirmed leptospirosis Patients 2014-2017(n=200)

\begin{tabular}{|c|c|c|c|c|c|c|}
\hline \multirow[t]{2}{*}{ Variable } & \multicolumn{2}{|c|}{ Leptospirosis n (\%) } & \multirow{2}{*}{$\begin{array}{l}\text { OR }(95 \% \text { CI }) \\
(95 \%)\end{array}$} & \multirow[t]{2}{*}{$p$-value } & \multirow[t]{2}{*}{ Adjusted OR } & \multirow[t]{2}{*}{$P$-value } \\
\hline & Confirm & Probable & & & & \\
\hline Cough & & & & 0.02 & & 0.02 \\
\hline No & $54(47.0)$ & $61(53.0)$ & $\operatorname{Ref}(1.00)$ & & $\operatorname{Ref}(1.00)$ & \\
\hline Yes & $54(63.5)$ & $31(36.5)$ & $0.51(0.29-0.90)$ & & $0.51(0.28-0.91)$ & \\
\hline $\begin{array}{l}\text { Abdominal } \\
\text { pain }\end{array}$ & & & & 0.03 & & 0.03 \\
\hline No & $95(57.6)$ & $70(42.4)$ & $\operatorname{Ref}(1.00)$ & & $\operatorname{Ref}(1.00)$ & \\
\hline Yes & $13(37.1)$ & $22(62.9)$ & $2.30(1.08-4.87)$ & & $2.30(1.07-4.93)$ & \\
\hline
\end{tabular}


Table V. Multivariate Logistic Regression

\begin{tabular}{lllllll}
\hline Variable & B & S.E. & Wald(df) & $p$-Value & $\begin{array}{l}\text { Corrected } \\
\text { OR }\end{array}$ & $95 \%$ C.I. \\
\hline Cough & -0.68 & 0.30 & $5.24(1)$ & 0.02 & 0.51 & $0.28-0.91$ \\
$\begin{array}{l}\text { Abdominal } \\
\text { pain }\end{array}$ & 0.83 & 0.39 & $4.59(1)$ & 0.03 & 2.30 & $1.07-4.93$ \\
\hline
\end{tabular}

creatinine kinase $(n=39)$, and $30.6 \%$ of patients had serum alanine aminotransferase (ALT) less than $50 \mathrm{U} / \mathrm{L}$ $(\mathrm{n}=33)$. A study in Brazil on 201 patients showed 82.4\% of patients had high AST, $74.3 \%$ of patients had low platelet count, $72.1 \%$ of patients had elevated ALT $_{2}$ $69.8 \%$ of patients had elevated white cell count. Their findings showed a higher number of patients having raised ALT, AST and low platelet count compared to our study. Thrombocytopenia has been associated with the worst prognosis. A study done in Thailand found reduced platelet count to be directly associated with the severity of leptospirosis. ${ }^{21}$ In our study, $36.1 \%$ of the patient had a low platelet count, and these patients may have a risk of developing severe leptospirosis.

Having poor sanitation and present of rodents in the house increases the risk of getting leptospirosis infection. Sik, which is considered as a rural area, have poor sanitation and garbage collection, especially in the villages. The reason for this is because villages do not come under the jurisdiction of the local municipal council. As such, they have weak garbage collection system and sanitation giving rise to suitable habitat for rat infestations. In our study, 100 patients (92.6\%) with confirmed leptospirosis live in villages, and $33.3 \%$ of patients had rat's infestation in their houses. A casecontrol study done in Salvador, Brazil showed that living in the rat-infested area and having poor sanitation increases the risk for leptospirosis infection. ${ }^{22}$ Similar findings were also seen in a study done by Ullmann LS (2011). In our research, most of the people have seen rodents in their houses, therefore, increasing the risk of getting leptospirosis infections.

\section{CONCLUSION}

Leptospirosis is a significant zoonotic disease, knowing the current situation of leptospirosis in Sik district will help the district health office to monitor the disease better and to carry out control and prevention measures.
Our study found exposure to recreational activities, poor sanitation and present of rodent in the houses as the primary source of infection for leptospirosis. In this study, many patients had rodent's infestation in their home, and fewer people were infected from recreation activities indicating that current promotion activities and campaign about the danger of leptospirosis from recreation activities have successfully raised public awareness and hence reduced leptospirosis cases from recreational activities. Therefore, in our promotion activities and campaign, it is vital to educate the community about cleanliness and no rodent infestations in houses to prevent leptospirosis infection.

\section{LIMITATION}

Being a cross-sectional study, data were obtained from patient's medical records; as such, not all the variables were available as they were not asked or recorded in the patient's record. Some of the laboratory tests were not done for all leptospirosis patients resulting in the exclusion of those patients.

\section{RECOMMENDATION}

To enhance the current strategy of promotion and campaign for leptospirosis by placing banners in villages, conducting radio talks, conducting talks in villages, engaging with village heads to educated them about leptospirosis infection and providing proper sanitation and garbage collection for villages to reduces rubbish around their houses, thereby reducing leptospirosis infection.

\section{ACKNOWLEDGEMENT}

We would like to thank the Director-General of Health Malaysia for his permission to publish this article. We would also like to thank Kedah State Health Director and Hospital Sik Director for permitting to conduct this research.

\section{CONFLICT OF INTEREST}

None declared. 


\section{REFERENCES}

1. Guernier, V. et al. Human Leptospirosis on Reunion Island, Indian Ocean: Are Rodents the (Only) Ones to Blame? PLoS Negl. Trop. Dis. 10, 1 -19 (2016).

2. Millán, J. et al. Leptospirosis in wild and domestic carnivores in natural areas in Andalusia, Spain. Vector-Borne Zoonotic Dis. 9, 549-554 (2009).

3. Lomar AV, Diament D, T. J. Leptospirosis in Latin America. 5520, (2000).

4. Ullmann, L. \& Langoni, H. Interactions between environment, wild animals and human leptospirosis. 17, 119-129 (2011).

5. Cassadou, S. et al. Underestimation of Leptospirosis Incidence in the French West Indies. PLoS Negl. Trop. Dis. 10, 1-10 (2016).

6. Abela-Ridder, B., Sikkema, R. \& Hartskeerl, R. A. Estimating the burden of human leptospirosis. Int. J. Antimicrob. Agents 36, S5-S7 (2010).

7. Pijnacker, R. et al. Marked increase in leptospirosis infections in humans and dogs in the Netherlands, 2014. Eurosurveillance 21, 1-7 (2016).

8. Hartskeerl, R. a., Collares-Pereira, M. \& Ellis, W.

a. Emergence, control and re-emerging leptospirosis: Dynamics of infection in the changing world. Clin. Microbiol. Infect. 17, 494-501 (2011).

9. Sharma, S., Vijayachari, P., Sugunan, a P. \& Sehgal, S. C. Leptospiral carrier state and seroprevalence among animal population--a crosssectional sample survey in Andaman and Nicobar Islands. Epidemiol. Infect. 131, 985-989 (2003).

10. Thayaparan, S., Robertson, I., Fairuz, A., Suut, L. \& Abdullah, M. T. Leptospirosis, an emerging zoonotic disease in Malaysia. malaysian j pathol 35 , 123-132 (2013).

11. Wasiński, B. \& Dutkiewicz, J. Leptospirosis -

Current risk factors connected with human activity and the environment. Ann. Agric. Environ. Med. 20, 239-244 (2013).

12. Lau, C., Smythe, L. \& Weinstein, P. Leptospirosis: An emerging disease in travellers. Travel Med. Infect. Dis. 8, 33-39 (2010).

13. Sethi, S. et al. Increasing trends of leptospirosis in Northern India: A clinico-epidemiological study. PLoS Negl. Trop. Dis. 4, 1-7 (2010).
14. Esmaeili, R., Hesamzadeh, A., Alizadeh-Navaei, R., Haghshenas, M. H. \& Alhani, F. Incidence of leptospirosis in Mazandaran Province, north of Iran: a one year survey. Pakistan journal of biological sciences: PJBS vol. 12 1330-3 (2009).

15. Tan, W. L. eong et al. Leptospirosis Incidence and Mortality in Malaysia. Southeast Asian J. Trop. Med. Public Health 47, 434-440 (2016).

16. THORNLEY, C. N., BAKER, M. G., WEINSTEIN, P. \& MAAS, E. W. Changing epidemiology of human leptospirosis in New Zealand. Epidemiol. Infect. 128, 29-36 (2002).

17. Cowie, G. \& Bell, A. A retrospective review of notified human leptospirosis cases in the Waikato region of New Zealand, 2004 to 2010. N. Z. Med. J. 125, 20-27 (2012).

18. Daher, E. F. et al. Clinical presentation of leptospirosis: a retrospective study of 201 patients in a metropolitan city of Brazil. Braz: J. Infect. Dis. 14, 3-10 (2010).

19. Vanasco, N. B. et al. Clinical characteristics and risk factors of human leptospirosis in Argentina (1999-2005). Acta Trop. 107, 255-258 (2008).

20. Morrissey, A. B. et al. Leptospirosis among Hospitalized Febrile Patients in Northern Tanzania. Am. J. Trop. Med. Hyg. 85, 275-281 (2011).

21. S., T. \& S., T. Prognostic Factors Associated with Severe Leptospirosis. J. Med. Assoc. Thail. 86, 925931 (2003).

22. Sarkar, U., Nascimento, R., B., For \& C.-C., M. Population-Based Case-Control Investigation Of Risk Factors For Leptospirosis During An Urban Epidemic . 66, 605-610 (2002). 